\title{
UM NOVO OLHAR SOBRE A DEFICIÊNCIA INTELECTUAL
}

Maria Elizabeth Barreto Tavares dos Reis

Universidade Estadual de Londrina

\section{Publicação}

Ferreira, S. L. (2015). Escrevendo outro script para a deficiência intelectual. Curitiba: Appris.

\section{RESENHA}

Solange Leme Ferreira é Psicóloga, graduada pela Universidade Estadual de Londrina (1977), especialista em Metodologia do Ensino Superior (UEL, 1981), mestre em Educação Especial (UFSCar, 1985) e doutora em Psicologia na área de Psicologia e Sociedade (UNESP, 2012). A autora é docente do departamento de Psicologia Social e Institucional da UEL, onde desenvolve diversos projetos de extensão integrados ao ensino e à pesquisa, abordando com sensibilidade e objetividade as questões relacionadas à deficiência intelectual. Dentre tais projetos, podemos citar o Programa de atendimento "precoce" a crianças portadoras da Síndrome de Down (iniciado em 1987) e mais tarde denominado Programa Síndrome de Down: atendimento preventivo à criança e respectiva família (1992-1994). O programa culminou com a fundação da Associação dos Pais e Amigos dos Portadores da Síndrome de Down - APS Down (1993), na cidade de Londrina. A partir dos estudos e da motivação em trabalhar com as pessoas cujas diferenças demandam atendimentos específicos, a autora contribuiu de forma efetiva para a implementação da Comissão Permanente de Apoio a Alunos Portadores de Deficiência (CODE), constituída por equipe multidisciplinar com representantes de diversos departamentos de ensino e coordenadorias administrativas da UEL, a qual foi reestruturada e nomeada como PROENE - Programa de Acompanhamento aos Estudantes com Necessidades Especiais, atualmente denominado NAC - Núcleo de Acessibilidade.

O seu trabalho voltado à desmitificação da deficiência intelectual, desenvolvido mediante projetos de extensão, resultou na publicação do livro "Aprendendo sobre a deficiência mental: um programa para crianças", Editora Memnon, São Paulo, 1998. Entrar em contato, em 1989, com um grupo de teatro integrado por atores com deficiência intelectual, o que, segundo as palavras da autora, Ihe desencadeou uma "paixão à primeira vista", foi o elemento propulsor de seu próximo projeto de extensão, o GTPAÊ: Grupo de Teatro para Atores Especiais (1997). Esta experiência propiciou à autora organizar o livro "Teatro e deficiência mental: a arte na superação de nossos limites", publicado pela editora Memnon, São Paulo, 2002; bem como também ensejou a criação da Associação Arte e Gente para viabilizar a continuidade 
daquele grupo de teatro quando o projeto de extensão universitária foi encerrado.

O livro "Escrevendo outro script para a deficiência intelectual", publicado pela Editora Appris em 2015, começa com a "Cena inicial - delineando a origem e o percurso da narração" na qual a autora faz a apresentação da obra redigida a partir da sua tese de doutorado.

No primeiro capítulo "Prazerosamente fazendo ciência hoje" apresenta a forma como se aproximou do tema e escolheu a metodologia da tradução memorial para comunicação de seu "testamento acadêmico" (p. 34).

No segundo capítulo "Traduzindo fatos atos e emoções na reconstrução social da deficiência mental" descreve a sua trajetória acadêmica, ressaltando as inquietações sobre o tema desde de 1976, ao cursar a disciplina Psicologia do Excepcional; a atuação como docente no ensino superior; e ampla experiência no âmbito da extensão universitária e interface com o ensino e a pesquisa. A escrita revela não apenas a seriedade do trabalho, ao mencionar a busca pela compreensão do universo vivenciado por aqueles que possuem a deficiência intelectual, mas também a preocupação em favorecer o seu atendimento preventivo, bem como às suas famílias, a conscientização da população sobre o tema e os desdobramentos dos projetos desenvolvidos tanto na comunidade universitária quanto na população em geral. Ao fechar as "cortinas do palco", no qual apresenta suas emoções vividas, a autora consegue mobilizar e motivar o leitor a conhecer as nuances do trabalho por ela desenvolvido.

No terceiro capítulo "Contando uma história de transformação e autonomia social", a autora compartilha suas indagações a respeito de como contribuir para melhorar compreensão da deficiência intelectual, mediante ações educativas destinadas à população em geral. A seguir apresenta suas considerações sobre a possibilidade de se fazer uso da arte como forma de propiciar a auto expressão e a comunicação de diferentes aspectos das situações vivenciadas pelas pessoas com a deficiência intelectual. Apresenta, então, a concepção e a trajetória do GTPAÊ (Grupo de Teatro para Atores Especiais) descritas de forma tal que conduz o leitor aos "Laboratórios de teatro", possibilitando imaginar a riqueza das emoções e dos insights obtidos pelos atores e o efeito das suas performances nas plateias onde já se apresentaram - eventos científicos, escolas, empresas e comunidade em geral - favorecendo a compreensão, o respeito e a admiração por essas pessoas tão especiais.

No quarto capítulo, "Organizando ideias sobre a deficiência intelectual na perspectiva social", após a descrever com sensibilidade, sutileza e objetividade tantas emoções vivenciadas em sua interação com as pessoas que possuem a deficiência intelectual, mediante os diversos projetos desenvolvidos, apresenta as suas considerações sobre "O lugar social da pessoa com deficiência intelectual". A autora convoca à reflexão sobre a maneira "como o indivíduo com a deficiência se inscreve na sociedade do século XXI" (p. 110) considerando os 
aspectos sócio-políticos da modernidade que contribuíram para as transformações que levaram o homem a vivenciar os fatos, atos e emoções de forma efêmera, desengajada e desapegada ao se relacionar com o mundo. Além disso, ressalta a questão da "informação/desinformação" que favorece a manutenção do lugar ocupado nos meios sociais vigentes e ampliam negativamente as dificuldades decorrentes de sua condição.

No quinto capítulo, "Escrevendo um novo script para a deficiência intelectual", a autora aborda a maneira como as pessoas com alguma deficiência eram consideradas e tratadas antes dos anos 80 e passa a discorrer sobre as alterações das concepções da deficiência intelectual onde ao invés da segregação busca-se a inclusão. A seguir apresenta suas ideias sobre " O novo olhar sobre a deficiência Intelectual - um caminho essencial" ressaltando a necessidade da sociedade se perceber e, nas palavras da própria autora, "desencadear uma reconstrução na dimensão axiológica (valores morais, éticos, estéticos) conceitual e afetiva da sociedade no que concerne à deficiência intelectual" ( $p$. 155). A partir de então enfatiza a necessidade de "uma parceria entre Psicologia e Mídia" visando uma "reconstrução social da deficiência intelectual".

No último capítulo "Cena final - iniciando a próxima história de reconstrução social da deficiência intelectual", relata as atividades desenvolvidas no projeto de extensão universitária através dos "LABOMIDI - Laboratórios de Mídia e Deficiência Intelectual" com participação de estudantes de diferentes áreas visando fomentar a reflexão crítica sobre as informações que são viabilizadas pelos meios de comunicação tanto em relação ao próprio tema quanto às pessoas com deficiência intelectual.

Finalmente, pode-se constatar que além de apresentar, em diferentes atos, a busca pela compreensão da condição de vida daqueles com deficiência intelectual, a autora expõe em diferentes cenários o ontem, o hoje e as possibilidades futuras para a percepção, o acolhimento, o reconhecimento e a aceitação de que no palco da vida encontram-se pessoas com características específicas e que o "tamanho único" não pode ser considerado o padrão comum.

\section{Sobre a autora}

Maria Elizabeth Barreto Tavares dos Reis é psicóloga, mestre pela PUC de Campinas e Doutora em Psicologia Clínica pela USP, docente do departamento de Psicologia e Psicanálise da Universidade Estadual de Londrina. Atua principalmente nas áreas de Psicologia Clínica, Saúde Mental, Tratamento e Prevenção. bethtavares@uel.br

Recebido em: 27/04/2016 Aceito em: 29/04/2016 